DOI: $10.19195 / 2084-5065.39 .9$

\title{
Fałszerstwa dokumentów operacyjnych a badania pismoznawcze
}

\author{
PIOTR HERBOWSKI
}

Katedra Prawa Karnego

SWPS Uniwersytetu Humanistycznospołecznego. Wydział Zamiejscowy w Poznaniu

\section{JACEK BUKOWSKI}

Laboratorium Kryminalistyczne Komendy Wojewódzkiej Policji w Bydgoszczy

\section{Wstęp}

Zagadnieniem, które nie było dotąd przedmiotem szerszej analizy $^{1}$, jest kwestia oceny wiarygodności dokumentów operacyjnych związanych z wynagradzaniem osobowych środków pracy operacyjnej, a głównie osobowych źródeł informacji ${ }^{2}$. Jest to istotne, gdyż jednym

1 Por. Z. Rau, Problematyka prowadzenia pracy operacyjnej Policji a bezpieczeństwo prawne policjanta i prokuratora, „Prokurator” 2007, nr 1, s. 18-20; także Z. Rau, Problematyka czynności operacyjno-rozpoznawczych $w$ świetle przeprowadzonych badań. Dziesięć lat prac nad ustawa — legislacyjna rozwaga czy porażka?, [w:] Przestępczość w XXI wieku - zapobieganie i zwalczanie. Problemy prawno-kryminologiczne, red. E. Pływaczewski, W. Filipkowski, Z. Rau, Warszawa 2015, s. 365-409; oraz R. Pawłowski, Bezpieczeństwo prawne funkcjonariuszy realizujacych czynności operacyjne w świetle obecnie obowiqzujacych unormowań prawnych, [w:] Przestępczość w XXI wie$k u \ldots$, s. 351-363.

2 Pojęciem tym będą określane osoby przekazujące poufnie informacje służbom państwowym, z którymi współpraca ma charakter stały, np. informatorzy, współpracownicy i agenci, jak też przekazujące informacje incydentalnie (jednorazowo), np. osoby anonimowe. Określenie osobowe źródła informacji będzie stosowane w tej publikacji 
z podstawowych motywów skłaniających do przekazywania informacji organom ścigania, a jednocześnie możliwym do wykorzystania w świetle obowiązujących regulacji prawnych, jest zainteresowanie materialne ${ }^{3}$. $\mathrm{Na}$ istnienie tego problemu jedynie sporadycznie wskazywano w opracowaniach naukowych opisujących działalność komunistycznych organów bezpieczeństwa ${ }^{4}$. Obecnie dostrzec można zdecydowanie więcej sygnałów dotyczących istnienia takich nieprawidłowości ${ }^{5}$. Takim, którego nie można zlekceważyć, są wyniki badań ankietowych przeprowadzonych przez Z. Raua wśród funkcjonariuszy operacyjnych policji. Zgodnie podnosili oni to, iż jednym z podstawowych problemów w prowadzeniu pracy operacyjnej jest obecnie wzajemna nieufność funkcjonariuszy korzystających z funduszu operacyjnego i ich przełożonych ${ }^{6}$. Niestety Autor tych badań nie podjął się wyjaśnienia faktycznych powodów tej nieufności. Kolejnym sygnałem jest zauważalna tendencja obniżania się poziomu jakości pracy operacyjnej, co wykazano m.in. w sprawozdaniu Sejmowej Komisji Śledczej ds. zbadania okoliczności porwania i śmierci Krzysztofa Olewnika ${ }^{7}$. Wskazano w nim m.in. na lekceważe-

zamiennie z informatorem. Przykładowy podział osobowych źródeł informacji przedstawili także R. Netczuk, Tajny wspótpracownik policji na tle prawnoporównawczym, Katowice 2006, s. 111-113 oraz E. Gruza, M. Goc, J. Moszczyński, Kryminalistyka czyli rzecz o metodach śledczych, Warszawa 2008, s. 67.

${ }^{3}$ K. Horosiewicz, Zagrożenia towarzyszqce wspótpracy policjantów z osobowymi źródtami informacji, [w:] Przestępczość w XXI wieku..., Warszawa 2015, s. 505.

${ }^{4}$ Zob. P. Skubisz, Fatszerstwa dokumentacji operacyjnej popetnione przez funkcjonariuszy Urzędu Bezpieczeństwa i Stużby Bezpieczeństwa, [w:] Osobowe środki pracy operacyjnej - zagadnienia źródłoznawcze, red. F. Musiał, Kraków 2013, s. 191-217; R. Szczypta-Szczęch, Zwolniony dla dobra stużby. Studium przypadku Jana Nowaka, [w:] Osobowe środki pracy operacyjnej - zagadnienia źródtoznawcze, red. F. Musiał, Kraków 2013, s. 155-189.

${ }^{5}$ Szerzej K. Horosiewicz, Wspótpraca policjantów z osobowymi źródłami informacji, Warszawa 2015, s. 175-176.

${ }^{6}$ Z. Rau, Czynności operacyjno-rozpoznawcze w polskim systemie prawa - dziatania w kierunku uniwersalnej ustawy, [w:] Praktyczne elementy zwalczania przestepczości zorganizowanej i terroryzmu. Nowoczesne technologie i praca operacyjna, red. L. Paprzycki, Z. Rau, Warszawa 2009, s. 722.

${ }^{7}$ Sprawozdanie Sejmowej Komisji Śledczej do zbadania prawidłowości działań organów administracji rządowej w sprawie postępowań karnych związanych z uprowadzeniem i zabójstwem Krzysztofa Olewnika, Druk Sejmowy nr 4205, s. 205-206, http:// www.marekbiernacki.pl/wp-content/uploads/2011/06/4205.pdf (dostęp: 6.01.2016). 
nie lub brak umiejętności prawidłowego dokumentowania czynności operacyjno-rozpoznawczych ${ }^{8}$.

\section{Fundusz operacyjny — aktualne problemy}

Problem fałszowania dokumentacji operacyjnej potwierdzającej przekazanie osobowym źródłom informacji środków finansowych z funduszu operacyjnego ${ }^{9}$ istnieje w Polsce nie od dzisiaj i może dotyczyć wszystkich służb posiadających uprawnienia do wykonywania czynności operacyjno-rozpoznawczych ${ }^{10}$. Problemu tego nie powinno się więc lekceważyć, z czym mamy obecnie do czynienia, choć rozmiarów ewentualnych nadużyć nie można dokładnie ustalić na podstawie dostępnych danych statystycznych ${ }^{11}$. Nie istnieje przecież odrębna kategoria czynów popełnianych w związku z realizacją czynności operacyjno-rozpoznawczych. Jeśli już są one ujawniane, mogą być wykazywane jako przestępstwa skierowane przeciwko wiarygodności dokumentów. Za szczególnie niepokojące trzeba uznać nadużycia w służbach specjalnych, gdzie powinna przecież funkcjonować bardzo dokładna kontrola współpracy z osobowymi źródłami informacji, a więc także ich wynagradzania. O tym, że tak nie jest, świadczy chociażby wyłudzenie z funduszu operacyjnego Agencji Wywiadu przez jej funkcjonariuszy około 1,5 mln $\mathrm{zl}^{12}$.

8 K. Horosiewicz, Współpraca policjantów..., s. 16-17.

9 Szerzej na temat funduszu operacyjnego M. Białuński, Fundusz operacyjny - aspekty normatywne i prawno-porównawcze, „Przegląd Policyjny” 2015, nr 1, s. 104-120.

10 M. Chrabkowski, Metody pracy operacyjnej, [w:] Przestępczość zorganizowana. Fenomen. Wspótczesne zagrożenie. Zwalczanie. Ujęcie praktyczne, red. W. Jasiński, W. Mądrzejowski, K. Wiciak, Szczytno 2013, s. 490-492.

11 Zob. M. Działoszyński, J. Wójcik, Zapobieganie i zwalczanie przestępczości w Policji na przykładzie działalności Biura Spraw Wewnętrznych Komendy Głównej Policji, [w:] Praktyczne elementy zwalczania przestęczości zorganizowanej i terroryzmu. Nowoczesne technologie i praca operacyjna, red. L. Paprzycki, Z. Rau, Warszawa 2009, s. $305-314$.

12 http://konflikty.wp.pl/kat,1020231,title,Dwoch-oskarzonych-o-przywlaszczenie-15-mln-zl-z-funduszu-Agencji-Wywiadu,wid,16362482,wiadomosc.html; http:// www.rp.pl/artykul/601122.html (dostęp 5.02.2014); http://wyborcza.pl/duzyformat/1,136811,15646815,W_polskim_wywiadzie_kase_defraudowano_od_lat_Gdy.html\#TRrelSST; oraz http://wyborcza.pl/1,75478,15659418,Dlaczego_ginie_kasa_w_Agencji_Wywiadu.html (dostęp: 6.04.2014). 
Do podobnych nadużyć miało również dochodzić w ostatnich latach w Centralnym Biurze Antykorupcyjnym ${ }^{13}$ oraz Służbie Kontrwywiadu Wojskowego ${ }^{14}$. Należy więc szukać odpowiednich rozwiązań, które usprawniłyby funkcjonowanie obecnie wysoce niedoskonałego systemu kontroli wynagradzania informatorów ${ }^{15}$, a nawet mogłyby stanowić swego rodzaju barierę psychologiczną przed podejmowaniem przez funkcjonariuszy takich przestępczych praktyk. Jednym z nich mogłoby być wykorzystanie badań pismoznawczych do szybkiej weryfikacji podejrzeń co do wykonawstwa dokumentacji operacyjnej.

\section{Przejawy nieprawidłowości}

Mechanizmy działań przestępczych związanych z funduszem operacyjnym są dość łatwo dostrzegalne dla osób znających tę problematykę. Przejawiać mogą się one chociażby w zbyt częstym wynagradzaniu osób informujących ${ }^{16}$. Ta kategoria źródeł nie jest rejestrowana ${ }^{17}$, w zwiazzu z czym sprawdzenie, czy dostarczone pokwitowanie odbioru wynagrodzenia zostało podpisane przez osobę, która faktycznie przekazała informację, jest bardzo trudne lub wręcz niemożliwe. Kolejny sposób to sporządzenie przez funkcjonariusza pokwitowania odbioru środków z funduszu niejako „na konto” zarejestrowanego i faktycznie prowadzonego informatora za informację przez niego przekazaną lub uzyskaną przez obsługującego źródło np. w toku czynności procesowych lub własnych ustaleń operacyjnych. Ponadto możliwe jest stwo-

${ }^{13}$ M. Pyza, M. Wikło, Przekręcona kasa CBA, „W Sieci” 19-25 października 2015, nr 42, s. 30-33.

$14 \mathrm{http} / / /$ wpolityce.pl/polityka/269040-w-jednostce-skw-zdefraudowano-polmiliona-zlotych-siemoniak-wydajemy-wielkie-publiczne-pieniadze-liczy-sie-troska-okazdy-grosz (dostęp: 20.10.2015).

15 Zob. P. Herbowski, The Problem of Proper Supervision of Superiors over Remunerating Personal Sources of Information, „Security Dimensions International \& National Studies" 2014, nr 12, s. 69-75.

16 Zob. sprawozdania z działalności kontrolnej prowadzonej w resorcie spraw wewnętrznych i administracji z lat 2006, 2008, 2009, 2010 i 2012 znajdujące się na stronie: bip.msw.gov.pl — w zakładce Kontrole.

17 E. Gruza, M. Goc, J. Moszczyński, op. cit., s. 66-67; R. Netczuk, op. cit., s. 111-113. 
rzenie przez funkcjonariusza całej dokumentacji fikcyjnego osobowego źródła informacji i przedstawianie dysponentowi funduszu operacyjnego sfałszowanych pokwitowań odbioru wynagrodzenia. Obecnie sprzyja temu to, że nawet bezpośredni przełożeni w większości przypadków nie weryfikują faktu współpracy policjanta ze źródłem, gdyż nie odbywają obowiązkowych spotkań kontrolnych ${ }^{18}$. Ich nadzór ma charakter pozorny lub wręcz zachowawczy ${ }^{19}$. Wynika to z coraz częściej zauważalnych odstępstw od wypracowywanych latami zasad współpracy $\mathrm{z}$ informatorami ${ }^{20}$. Jest to możliwe, gdyż, jak trafnie zauważył K. Horosiewicz — były Dyrektor Biura Kontroli Komendy Głównej Policji — kontrole z jednostek zwierzchnich służą przede wszystkim formalnemu sprawdzeniu dokumentacji potwierdzającej współpracę ${ }^{21}$ oraz wypłatę wynagrodzeń.

\section{Studium przypadku}

Do podjęcia tych rozważań skłoniła autorów sprawa prowadzona w jednej z komend powiatowych policji, w której swoje działania kontrolne podjęli funkcjonariusze Biura Spraw Wewnętrznych Komendy Głównej Policji (dalej BSW KGP). Zostały one zainicjowane po uzyskaniu przez nich wiarygodnej informacji dotyczącej możliwości fałszowania dokumentacji operacyjnej przez funkcjonariuszy pracujących w tej jednostce Policji. Analizie poddano wybrane dokumenty powstałe w ciągu ostatnich dwóch lat, których wytwórcami byli dwaj funkcjonariusze pionu operacyjnego. Jej wyniki potwierdziły podejrzenia co do autentyczności blisko dwudziestu pokwitowań odbioru środków pieniężnych pochodzących z funduszu operacyjnego. Na tych pokwitowaniach informatorzy powinni własnoręcznie potwierdzać odbiór pieniędzy za

18 K. Horosiewicz, Nadzór przełożonych nad wspótpraca policjantów z osobowymi źródłami informacji, „Przegląd Policyjny” 2013, nr 3, s. 246.

19 Ibidem, s. 246-247.

20 Por. P. Skubisz, op. cit., s. 191-217 oraz R. Jaworski, Aktualne zagadnienia informacji i dowodów pochodzacych ze źródel osobowych, [w:] Czynności procesowo-kryminalistyczne $w$ polskich procedurach, red. V. Kwiatkowska-Darul, Toruń 2004, s. $129-130$.

21 Por. K. Horosiewicz, Nadzór przełożonych ..., s. 241-242. 
przekazanie informacji, które dotyczyły przestępstw popełnionych na terenie podległym kontrolowanej jednostce policji. Treść każdego z tych dokumentów składała się z kilku odręcznie nakreślonych zdań, finalizowanych podpisem złożonym wyłącznie z inicjałów. Większość poddanych analizie pokwitowań była sporządzona pismem zaburzonym. Jednak mimo tego funkcjonariusz, który je sprawdzał i nie posiadał żadnego przygotowania w zakresie kryminalistycznych badań pismoznawczych, w związku z podobnym typem grafizmów i faktem sygnowania dokumentów innymi inicjałami, powziął uzasadnione podejrzenie, iż wykonawcą tychże dokumentów może być jedna osoba.

W związku z tym, iż funkcjonariusze BSW KGP za najbardziej prawdopodobne uznali, iż osobowe źródła informacji mogą być fikcyjne, a cała dokumentacja współpracy z nimi została stworzona wyłącznie przez policjantów operacyjnych, prokuratura okręgowa wszczęła w tej sprawie postępowanie przygotowawcze. Kluczową rolę odegrały w nim badania pismoznawcze, w których wyniku upatrywano szansy na weryfikację zaistniałych podejrzeń. W związku z tym całość zebranego materiału dowodowego w postaci pokwitowań odbioru środków pieniężnych z funduszu operacyjnego została przekazana biegłemu z dziedziny klasycznych badań pismoznawczych. Celem prowadzonych badań było ustalenie, czy odręczne zapisy i podpisy stanowiące zasadniczy tekst kwestionowanych dokumentów zostały nakreślone przez któregoś z dwóch funkcjonariuszy, którzy swoimi adnotacjami potwierdzali przekazanie wyszczególnionych w pokwitowaniach kwot pieniędzy. Dzięki temu, iż uzyskano dużą ilość materiału do badań, pomimo silnych deformacji zapisów wynikających z chęci maskowania ,autografizmu” ich wykonawcy(ów), prowadzącemu badania udało się wyselekcjonować zespół silnie zindywidualizowanych cech graficznych jednej osoby na kilkunastu pokwitowaniach sygnowanych podpisami (inicjałami) różnych osób.

Kolejną kwestią, którą należało rozwiązać, było wytypowanie odpowiedniego materiału porównawczego pochodzącego od podejrzewanych o ich autorstwo funkcjonariuszy. Biorąc pod uwagę, że mogli, a nawet powinni oni liczyć się z ewentualną, mniej lub bardziej wnikliwą, weryfikacją przedkładanych przełożonym pokwitowań, wydawało się, iż grafizmy na nich widniejące zostaną dość skutecznie zamaskowane. W sy- 
tuacji braku jakiegokolwiek materiału porównawczego pochodzącego od informatorów mogło to przecież skutkować pozbawieniem biegłego jakichkolwiek możliwości ustalenia wykonawcy(ów) zapisów. Po przeanalizowaniu całości otrzymanego materiału dowodowego zwrócił się on do prowadzących postępowanie przygotowawcze o dostarczenie mu jak najliczniejszych bezwpływowych wzorów zapisów sporządzonych przez podejrzewanych funkcjonariuszy ${ }^{22}$. Powinny one pochodzić z lat obejmujących wszystkie kwestionowane pokwitowania z możliwością ewentualnego ich poszerzenia o zapisy sprzed roku od daty pierwszego pokwitowania i analogicznie z okresu roku po dacie ostatniego z nich. Miało to na celu sprawdzenie ewentualnych modyfikacji graficznych wynikających z długookresowego procederu konieczności mniej lub bardziej udolnej zmiany w obrazie cech pisma. Materiał porównawczy przekazany biegłemu zawierał wyłącznie dokumenty procesowe związane z obowiązkami służbowymi wytypowanych funkcjonariuszy, tzn. protokoły oględzin lub protokoły przyjęcia zawiadomienia o popełnionym przestępstwie oraz notatki.

W efekcie kilkutygodniowych badań graficzno-porównawczych ekspert kategorycznie ustalił wykonawstwo kilkunastu kwestionowanych dokumentów. Wszystkie zostały sporządzone wyłącznie przez jednego z dwóch podejrzewanych funkcjonariuszy operacyjnych, którzy mieli współpracować z osobowymi źródłami informacji. Co ciekawe, sformułowana w opinii pismoznawczej jednoznaczna konkluzja spowodowała, że uznano za konieczne zweryfikowanie innych pobocznych dokumentów związanych z wydatkowaniem środków z funduszu operacyjnego. Dotyczyło to przede wszystkim notatek służbowych/raportów potwierdzających fakt osobistego uczestnictwa we ,wręczaniu” tychże wynagrodzeń przez funkcjonariusza asystującego.

22 Szerzej na temat konsultacji organu procesowego z biegłym badań pismoznawczych zob. R. Cieśla, Wstęna konsultacja organu procesowego z osoba posiadajaca wiadomości specjalne. Teoria a praktyka, [w:] Nauka wobec prawdy sqdowej - Księga Pamiatkowa ku czci Profesora Zdzisława Kegla, red. R. Jaworski, M. Szostak, Wrocław 2005, s. 82-83. 


\section{Możliwości wykorzystania badań pismoznawczych}

Takie sytuacje, jak wyżej opisana, mogą mieć miejsce, gdyż pokwitowania odbioru wynagrodzenia przez informatorów, przedstawiane przez obsługujących ich funkcjonariuszy dysponentom funduszu operacyjnego, nie są najczęściej, niestety, porównywane z innymi pokwitowaniami podpisanymi przez to samo źródło. Nie można też zapominać, że dysponenci funduszu nie posiadają żadnej specjalistycznej wiedzy $\mathrm{z}$ obszaru badań pismoznawczych. Ponadto takie pokwitowania mogą być, zgodnie $\mathrm{z}$ obowiązującymi przepisami, podpisywane parafą lub pseudonimem nakreślonym wielkimi literami ${ }^{23}$. Zidentyfikowanie ich wykonawcy może więc stanowić bardzo duże wyzwanie dla eksperta badań pismoznawczych i być obciążone sporym ryzykiem błędu. Źródeł trudności związanych z ewentualnym opiniowaniem należy upatrywać jednak przede wszystkim w braku odpowiedniej jakości i ilości materiału porównawczego potrzebnego do wydania kategorycznej opinii ${ }^{24}$. Od osobowych źródeł informacji nie uzyskuje się już obecnie praktycznie żadnych materiałów na piśmie w postaci życiorysu, spisu członków rodziny i znajomych, a przede wszystkim własnoręcznie napisanych donosów ${ }^{25}$. Jednak szczególnie niepokojące jest to, że tzw. zobowiązania do współpracy przybrały, np. w policji, postać formularza, do którego informator wpisuje jedynie pseudonim przyjęty w celu konspiracji. Trzeba to szybko zmienić, by te zobowiązania były sporządzane w całości pismem

23 Zarządzenie nr pf-634 KGP z dnia 30 czerwca 2006 r. w sprawie metod i form wykonywania przez Policję czynności operacyjno-rozpoznawczych, niepublikowane; Zarządzenie nr pf-1292/08 KGP z dnia 19 grudnia 2008 r. zmieniające zarządzenie w sprawie metod i form wykonywania przez Policję czynności operacyjno-rozpoznawczych, niepublikowane; Zarządzenie nr pf-671/11 KGP z dnia 7 czerwca 2011 r. zmieniające zarządzenie w sprawie metod i form wykonywania przez Policję czynności operacyjno-rozpoznawczych, niepublikowane.

24 Zob. T. Tomaszewski, Materiat porównawczy - kluczowy problem $w$ ekspertyzie podpisów, „Człowiek i Dokumenty” 2012, nr 27, s. 55-64; oraz T. Widła, Badania dokumentów, [w:] Kryminalistyka, red. J. Widacki, Warszawa 2008, s. 228-229.

25 Por. F. Musiał, Podręcznik bezpieki. Teoria pracy operacyjnej Stużby Bezpieczeństwa $w$ świetle wydawnictw resortowych Ministerstwa Spraw Wewnętrznych PRL (1970-1989), Kraków 2007, s. 114. 
ręcznym, a także podpisywane imieniem i nazwiskiem osobowego źródła informacji, tak jak to miało miejsce przed rokiem $1989^{26}$.

Uzyskanie odpowiedniego materiału porównawczego od funkcjonariusza operacyjnego, zarówno wpływowego, jak i bezwpływowego, bez wszczęcia postępowania karnego wydaje się obecnie dość problematyczne. Trudno sobie też wyobrazić, by dysponent funduszu operacyjnego powziął jakieś watpliwości co do autentyczności przedkładanych mu pojedynczo pokwitowań i skorzystał z pomocy eksperta badań pismoznawczych jako konsultanta operacyjnego ${ }^{27}$. Kolidowałoby to przecież z nadrzędną zasadą ochrony źródła informacji. Przede wszystkim jednak miałoby negatywny wpływ na dalszą karierę takiego przełożonego, który musiałby wystapić na podstawie art. 34 ust. 5 pkt 1 Ustawy o ochronie informacji niejawnych ${ }^{28}$ do Komendanta Głównego Policji o wyrażenie zgody na jednorazowe udostępnienie określonych informacji niejawnych osobie nieposiadającej odpowiedniego poświadczenia bezpieczeństwa. Trzeba dodać, że obowiązujące regulacje prawne pozwalają, by przełożony w trakcie spotkania kontrolnego uczestniczył w wypłacaniu informatorowi wynagrodzenia za przekazane informacje i sporządzaniu przez niego pokwitowania odbioru. Postrzegane byłoby to jednak dość powszechnie jako wyraz jego braku zaufania do podwładnego. Takie postępowanie mogłoby jednak przynieść istotne korzyści wówczas, gdy dysponent nabiera podejrzeń odnośnie autentyczności kolejnych pokwitowań. Posiadanie sporządzonych przez osobowe źródło informacji pokwitowań oraz zobowiązania pozwoliłoby mu na ich wstępną analizę, a następnie na ewentualne wdrożenie ww. procedury lub wszczęcie postępowania przygotowawczego, w trakcie których ekspert badań pismoznawczych miałby możliwość co najmniej wykluczenia faktycznego informatora jako wytwórcy pokwitowania.

\section{Ibidem.}

27 Zob. A. Taracha, Czynności operacyjno-rozpoznawcze, aspekty kryminalistyczne i prawnodowodowe, Lublin 2006, s. 188-201; I. Kordas, Rola eksperta w pozaprocesowych ustaleniach faktycznych - kontrola korespondencji w ramach czynności operacyjno-rozpoznawczych, [w:] Problematyka dowodu z ekspertyzy dokumentów, t. II, red. Z. Kegel, Wrocław 2002, s. 939-942; idem, Kryminalistyczne aspekty pism anonimowych. Rola konsultanta w pracy operacyjnej. Cz. 1, „Kwartalnik Policyjny” 2007, nr 2, s. 8-14; idem, Kryminalistyczne aspekty pism anonimowych. Rola konsultanta w pracy operacyjnej. Cz. 2, „Kwartalnik Policyjny” 2008, nr 1, s. 24-29.

28 Dz. U. z 2010 r. Nr 182, poz. 1228. 


\section{Nieprawidłowości w nadzorze nad współpracą $\mathrm{z}$ informatorami}

W piśmiennictwie wskazuje się, że obecnie zawodzi w policji doskonalony przez wiele lat system nadzoru nad współpracą z osobowymi źródłami informacji ${ }^{29}$. Do ujawniania przestępczej działalności związanej z wyprowadzaniem środków z funduszu operacyjnego dochodzi więc rzadko $i$ tylko przez przypadek ${ }^{30}$. Spowodowane jest to brakiem systematycznej i szczegółowej kontroli działań funkcjonariuszy operacyjnych ze strony bezpośrednich przełożonych ${ }^{31}$, a przecież jedną z podstawowych ról, jakie powinien pełnić właściwy nadzór przełożonych, jest zabezpieczenie się przed fałszowaniem dokumentacji przez szeregowych funkcjonariuszy danej służby ${ }^{32}$.

W celu większej kontroli wspólpracy z informatorami wprowadzono $\mathrm{w}$ policji instytucję policjanta asystującego ${ }^{33}$. Wydaje się jednak, iż wbrew twierdzeniom decydentów o konieczności zapewnienia ciagłości współpracy z osobowym źródłem informacji w przypadku nieobecności policjanta prowadzącego, w praktyce miała służyć w głównej mierze kontroli prawidłowości wydatkowania środków z funduszu operacyjnego. Nie została jednak dostosowana do specyfiki policyjnej pracy operacyjnej ${ }^{34}$. Odnoszące się do niej przepisy są więc przestrzegane najczęściej formal$n^{35}{ }^{35}$. W dokumentacji sporządzanej ze spotkania znajduje się wówczas adnotacja potwierdzająca udział policjanta asystującego, podczas gdy faktycznie w nim nie uczestniczył. Taka też sytuacja mogła mieć miejsce w analizowanym przypadku, i wówczas policjant naraża się na postępo-

29 Zob. K. Horosiewicz, Nadzór przełożonych..., s. 246-247.

30 http://wiadomosci.gazeta.pl/wiadomosci/1,114871,12094058,Okradali_policyjny_fundusz_Dlaczego_zginal_policyjny.html (dostęp: 5.02.2014).

31 P. Herbowski, Wybrane instrument prawne stużace zwalczaniu przestępczości zorganizowanej w Polsce. Analiza krytyczna, [w:] Zwalczanie piractwa, terroryzmu i przestępczości zorganizowanej. Aspekty historyczne, prawne i praktyczne, red. A. Aksamitowski, M. Cupryjak, Szczecin 2015, s. 311.

32 Por. F. Musiał, op. cit., s. 138.

33 K. Horosiewicz, Nadzór przełożonych..., s. 245.

34 Szerzej P. Herbowski, Some problems of cooperation of police officers with informants, „Nowa Kodyfikacja Prawa Karnego” 34, 2014, s. 119-132.

35 http://pokazywarka.pl/wspolczesni_agenci/(dostęp 5.02.2014). 
wanie karne związane z poświadczeniem przez niego nieprawdy w dokumentacji operacyjnej oraz niedopełnieniem obowiązków służbowych.

Prawie całkowicie zapomniano, że system kontroli wewnętrznej istniejący przed rokiem 1989 zapewniał możliwość dokładnej weryfikacji prowadzonych działań operacyjnych, w związku z czym stosunkowo rzadko organizowano spotkania kontrolne $\mathrm{z}$ udziałem przełożonego funkcjonariusza prowadzącego ${ }^{36}$. Ponadto system dokumentowania pracy osobowych źródeł informacji nakładał wówczas obowiązek szczegółowego charakteryzowania źródeł i okoliczności uzyskiwania informacji. Przełożeni mieli niemal pełną kontrolę nad metodami stosowanymi w trakcie realizacji wyznaczonych zadan ${ }^{37}$. Należałoby więc skorzystać z niektórych wypracowanych już przed laty rozwiązań służących lepszej kontroli współpracy funkcjonariuszy służb policyjnych i specjalnych z informatorami. W szczególności dotyczy to obowiązku uzyskiwania od źródeł informacji własnoręcznie sporządzonych zobowiązań do współpracy i pokwitowań odbioru wynagrodzenia. Ta procedura powinna oczywiście dotyczyć tylko rejestrowanych źródeł, a nie tych które przekazująjednostkowo informacje.

\section{Podsumowanie}

Przedstawione w tym opracowaniu kwestie, pomimo iż nie są nowe, nie doczekały się jednak jak dotąd żadnych szerszych analiz, a przede wszystkim wskazania koniecznych środków zaradczych. Jest to istotne, gdyż problemy te same nie znikną, a wręcz przeciwnie - będą wciąż narastać. Wynika to w dużej mierze z jedynie formalnej kontroli współpracy z osobowymi źródłami informacji, co wydaje się być katalizatorem przestępczych praktyk. Są one dość trudne do wykrycia na skutek m.in. odejścia od własnoręcznego sporządzania przez informatorów dokumentacji potwierdzającej fakt ich współpracy z organami ścigania.

W niniejszej publikacji dowiedziono, iż w sytuacji ujawnienia opisanych nieprawidłowości bardzo przydatne mogą być kryminalistyczne badania pismoznawcze. By wzrosła ich efektywność, trzeba wprowa-

36 R. Netczuk, op. cit., s. 88.

37 Ibidem, s. 105-106. 
dzić odpowiednie uregulowania prawne zapewniające zdecydowanie większą dostępność do spersonalizowanego materiału porównawczego pochodzącego od osobowych źródeł informacji. Mogłoby to nie tylko ograniczyć proceder fikcyjnego ich wytwarzania przez funkcjonariuszy, ale też, co chyba istotniejsze, stanowić pewnego rodzaju psychologiczną barierę przed podejmowaniem przez nich takich przestępczych praktyk z uwagi na potencjalnie duże ryzyko ich wykrycia. Konieczne jest więc wprowadzenie obowiązku sporządzania zobowiązań do współpracy w całości pismem ręcznym i podpisywanie ich imieniem i nazwiskiem przez informatorów, a także warunkowanie wypłaty wynagrodzenia za informację koniecznością własnoręcznego sporządzenia pokwitowania przez osobowe źródło informacji. Odstępstwo od tych wymogów powinno mieć charakter wyjątkowy i mogłoby być warunkowane np. określoną wysokością wypłacanej kwoty. Postulatu tego nie można uznać za anachroniczny, gdyż jest $\mathrm{w}$ pełni uzasadniony analizą obecnej sytuacji w zakresie współpracy z osobowymi źródłami informacji.

\section{Operational documents forgery and handwriting examinations}

\section{Summary}

The problem of operational documents forgery has been existing in the police and special forces for many years. It should not, however, be underestimated, as it results from insufficient supervision of their superiors. Handwriting examinations are useful in detecting and proving above mentioned practice, but also may provide a kind of psychological barrier against taking such criminal activities.

Keywords: handwriting examinations, operational documentation, operational work, forgery. 